\title{
An Attempt to Discern the Grounds for Studies of American History in Denmark
}

By

\author{
Niels Thorsen \\ Associate Professor, University of Copenhagen
}

Sigmund Skard argued in his work, American Studies Abroad, that American studies were justified on two grounds, which were combined in a notion of American "power of spiritual leadership in a struggling world." The progress of American studies, Skard wrote, was "primarily due to the simple pressure of events. Discrepancy between the position of the United States in the world and its place in syllabuses and curricula had long been growing; after 1945 it proved intolerable."1 In addition to such "realism and enlightened self-interest in European minds," Skard's work itself embodies the assumption of the moral and political significance of America as an "inspiration to the world in the past." America had "its main existence" in the European mind as "a symbol of general tendencies in Western Civilization." The study of America was therefore not "a sign of cultural submissiveness," but was to be seen as an essential contribution "to the understanding of ourselves.", The sheer fact of American power was not enough to account for the location of American studies within the European university. The significance of Skard's formulation lies in his insistence that the fact of American power be supplemented with a positive addition to man's existence.

Skard's notion of American leadership is no longer tenable. It carries no moral persuasion in a world that has witnessed the endless war crimes against a small country which, though it presented no military threat to the United States, delivered it a stinging political, moral, and military defeat. The years of political abasement, following the defeat in Vietnam, demonstrated that the house 
of the Republic was divided against itself. The lack of scholarly substance in the notion of American spiritual leadership can most briefly be indicated with reference to the last fifteen years of American history, during which virtually every major presidential address has centered upon the need to restore the loss of world superiority. The notion of world leadership is now cherished mainly among those who want to use "America" as a verbal front for their promotion of values that belong to various sorts of capitalism and imperialism, recently updated as "supply-side economics" and "world interdependence". To put the argument more precisely: the exercise of world power and the content of the values that were seen by Europeans as the most important part of the American cultural and political tradition were no longer and could no longer be understood as a unity. They were most often understood as two opposing sets of principles, one tied to class or elite control of technological forms of power, the other associated with historic and popular forms of authority.

Before the notion of American leadership is abandoned to rightwing exploitation which is too familiar to deserve much attention here, one might want to give second thoughts to the distinctive kind of historical dignity which is a mark of Skard's writing. One may ponder why Skard, in 1960, chose to defer his own notion to the formulation of a Norwegian woman who had once told him why she listened to the speeches of Franklin D. Roosevelt on her illegal radio during the German occupation. She said:

It's amazing about that President of the United States. He is speaking across thousands of miles of ocean; and still, he seems to speak directly to me, about everything we have to suffer here. ${ }^{3}$

The following attempt to explore the significance of American history in Denmark is an exercise in reflection, based upon this fragment which Skard has invested with symbolic meanings. But unlike Skard's account of American studies, the present attempt will be presented as a theoretical rather than as a historical venture. Skard, it will be recalled, did not specifically want to lay out the grounds for American history, but sought instead to deal with the full scope of literary, geographical, anthropological, political, economic, and cultural interests in American life. While the historical mode of explanation was appropriate for his broader purpose, it is equally clear that it will not do for a specific jusification of historical studies of the United States in Denmark. Historical 
activity cannot give an account of itself with reference to history. It must seek other grounds. The context chosen here is that of political community.

The turn to political theory may be kept in mind when the use of quotations is put to scholarly judgment. In theory, quotations do not primarily serve the functions of verification and documentation that historians are most familiar with. Rather, they serve the purpose of locating authority for a certain perception or idea. The quotations have significance as suggesting a certain mode of thought and discourse with its own conventions for the sharing of knowledge. The appearance of these fragments signifies a recognition that not only have the important features of one's questions been long anticipated, but that, indeed, whatever conviction these questions may carry in public, is carried principally by virtue of their anticipation.

\section{The Place of the Historian within the Political Community}

A few remarks on traditional conceptions of political community' and the historian's role within it are necessary at the outset. "The political" - the precise translation of which is "fellesskabet", that which is made or done in common - referred from its discovery in ancient Greek culture to what was common or shared among the members of a collectivity, such as a city, a society, a nation, or a people. Karl Marx, who discovered that political existence was founded upon shared labor, may be seen as the last proponent of this classical understanding. The peculiar authority that was accorded to the political order depended upon its ability to speak and act in the name of the whole, just as membership in the political community signified involvement in forms of life that were common to its members. The Danish word for political community embodies an additional meaning, which was implied in the Greek understanding, but which has been lost in the English use of the derivation from "polis" as an adjective rather than as a substantive. That which is common to a group of people is created in a radical sense. It must constantly be re-constituted and re-affirmed in order to be in the world. It is constantly threatened by "natural" forces of separation, inequality, and exclusiveness. There is no historical necessity that a society should aspire to be political. "Denmark", however, has manifested its political intentions at various stages of its history. One stage was signified by the preamble to 
"Fyske lov" from 1241, where it was proclaimed that the land was built by law. Constitutional principles and practice, signified by an order of government by the people, contain other dramatic claims to the political nature of the land.

The root meaning of the word "history", is that of "examining", "inquiring", and "making judgments". In a society that aspires to be political, the role of the historian is best understood as the role of a guardian of collective memory. He or she has privileged access to historical knowledge and he or she has been invested with special responsibilities by society at large. The historian must see to the comprehensiveness as well as to the accuracy of public recollection. He or she must see to its preservation as well as to its renewal.

It may well be that societies that have adopted aristocratic, autocratic, or bureaucratic modes of government have created different roles for the historian. But a society that boasts of itself as a democracy - "et folkestyre" - has created a role which requires that the historian should aspire to tell the truth about the foundation and changing fortune of collective life, including, of course, notions, beliefs, and actions that relate to neighboring or distant people. The dignity and value of this role stems in large measure from the importance of shared memories as part of common concerns, just as the language is shared in most political societies and just as the natural resources and the common boundaries are understood as shared obligations. The historian takes part in the political education of fellow citizens.

The historian, therefore, cares about a mode of speech, fit for public deliberation and action, that incorporates the historical experiences and understandings peculiar to the people. The kind of knowledge which the historian presides over in a democracy is one that extends over the length and breadth of past societies, just as it attempts to mark the depth of historical accretions. He or she has a specific responsibility to keep uncomfortable or even embarrassing memories in public sight in order to counteract the natural tendencies of a dynamic society to banish shameful events, despised minorities, exploited classes, and unfashionable styles of political expression from attention. Organized heedlessness is an important part of the process whereby the rulers' ideas are turned into the ruling ideas. The historian, in contrast, seeks to enlarge public consciousness. In this way he or she hopes to make a small contribution to the preservation of a varied and lively community in a democratic setting, based upon the belief that democracy itself 
depends upon "making political experience - the true basis of equality - accessible to all."4

The wilfulness of a people may well be seen as a cause as well as a consequence of its cultivation of historical resources, the identities accumulated over time, that make it possible to resist the many forces that conspire to dismember the body of the people and divide it into separate interests, denuded of common concerns. The modern state, it is well known, is committed to another kind of "resources". The economy needs a work force that is forgetful, adaptable, submissive, and mobile, so that it will be easy to direct according to the dictates of efficiency and profit. The bureaucracy needs an anonymous population that will readily conform to administrative expectations and scientific predictions, calculated on the basis of central filing systems. The market needs an army of grateful consumers, marching single file to the check-out counters. The political system needs a voter who willingly descends into powerlessness and obsequiousness between elections. The party system has begun to develop a systematic appeal to the lower instincts of the voter in a ritual that prepares one for a grateful acceptance of the investiture of the servants of economic science and administrative competence. In sum, the modern state system increasingly depends upon the manipulation of the citizen to substitute for the loss of public commitment and moral practices which were earlier seen to constitute the grounds for a democratic polity. The eradication of shared memories and their replacement with news and information engendered by modern mass media is an important part of this project. A politics of collective memory results, as new informational systems move in and appropriate parts of the public consciousness which were earlier occupied by traditional institutions, such as class, family, school, and local life.

\section{The Danish Revision of America}

The modern politics of perceptions of America in Denmark began after the end of the Second World War. Throughout the nineteenth century, official attitudes were characterized by a profound ambivalence towards American political and cultural values. The egalitarian image of America did not square well with Danish administrative and authoritarian traditions. The totalitarian experience, however, temporarily discredited established forms of politics and even brought reminders of the people as a political 
actor at war with its legitimate government, the dominant party system, and the bureaucratic order. The restoration of representative rather than participatory democracy after the war depended in part upon the ability of the established parties to revise and depoliticize the popular undercurrents seen to inhere in American history and associated both with anti-colonialism and with radical liberalism as voiced by Thomas Paine and restated in Tocqueville's understanding of American democracy as an alliance between liberalism and localism. The new understanding was heavily indebted to Gunnar Myrdal's view of America in the image of a partnership between liberalism and centralized government, which displaced Tocqueville's loyalty to political values with Myrdal's affection for social scientific engineering. ${ }^{5}$ Political freedom, meaning political participation, was translated as social opportunity. The idea of "a New World" had traditionally carried disturbing implications of a democratic challenge to the powers that be - forcefully summed up by Lincoln in 1862: "As our case is new, so we must think anew and act anew". This understanding gave way to a notion of "the Modern World" with technology as the dominant ideology to end all ideologies and with crafty management of the conflict between labor and capital to secure economic growth.

This official revision of the image of America may be illustrated with reference to changing Danish perceptions of other Scandinavian countries. After the war, Norway was held in high regard, due to its armed resistance to Germany; the Swedish accommodation to Nazi pressures was treated with deferred judgement, if not with suspicion. In the course of the 1950's, these sentiments were overlaid with admiration for Swedish industrial and social efficiency, while Norway was talked about in terms that hinted at social backwardness. The dominance of the official Danish interpretation of America became clear when it was briefly challenged in the late 1960 's. The discovery of what was often referred to as "the Second America" brought a bewildering variety of cultural and political protests against "the establishment" to the public attention. The active search for political participation and community that were perceived in American "grassroots" came to play a role in Danish notions of community-organizing.

The official revision of America, however, was carried out on different premises. Unlike normal ideologies, technological values assert themselves with reference to necessity, not with reference to 
freedom. The approved view of America was promoted by way of material values that may be distinguished on three levels. First, and perhaps most easily noticed, is the level of material things, products and goods, which occupy the consciousness of production and consumption. Secondly, one may point to a level of technology, organization, and "know-how", covered by the modern notion of "models". Thirdly, and most interesting for the present purpose, is the level which accounts for the reshaping of the world to make it fit for certain products and a certain technology. A television set needs a certain kind of society in order to make sense, as does an axe of stone for that matter. A computer is not a device of government for all worlds. A car calls for a peculiar system of roads. Motor highways, in turn, create a distinct interpretation of reality, an experience of nature which is homogenized, not only because of the uniform speed with which natural scenery is approached, but also because of the economics of highway construction, which requires that highways be placed in landscapes with certain geographical and socio-economic characteristics. On the level of the American creed, a new identity is created by the logic which dictates that tools in and by themselves are instructing man about what to do and how to think. Tools and techniques are formative principles behind the imaginative reconstruction of reality. The three levels of the translation of the American image into social-democratic practice corresponds to the eradication of traditional placebound skills, knowledge, and capacity for moral discernment, accumulated over time.

The incorporation of television into the Danish state provides an illustration of how official appeal to a product, vaguely associated with American ways, was used to effect a new national organization, a restructuring of public perception, and radical changes of daily life. The significance of the new product in Denmark is best seen when TV is translated as the ministry for public beliefs. Television was established upon an economics of scale, drawn to its logical limit, since the additional consumer (the viewer) within the monopolized market could be supplied at no costs whatsoever for the producing system. Television rests on a technology which dictates the enactment of two principles for what constitutes public knowledge, both of which contradict the historical understanding of knowledge. The first principle teaches the citizen that recent events are more important than events that are further removed in time. The second principle teaches the citizen to favor images which 
reflect events that are photographically focussed, planned, and organized above events that are spontaneous and without an organized center.

The establishment of television as the dominant form of public attention gave the state a new kind of control over the representation of the United States that was to be projected upon the public consciousness. Television replaced a large variety of sources of information and a diversity of interpretations that inhered in earlier acquaintance with America, such as the reading of historical works and travelling accounts, personal letters, personal contact with Americans abroad and with Danes returned from the United States, etc. Instead, commentators and experts came to act as guides to the almost daily telecasts from across the Atlantic. The presentation of America is now carried on in a variety of styles that can be described with reference to its extremes. At one extreme, the direct transmission of space explorations presents a mindless, sycophantic celebration of technological power. The Danish citizen is taught that tax-payers should have the foresight to invest their money in long-range planning for super-human adventure. The citizen is taught to regard esoteric expertise with awe and to look at traditional forms of power with contempt. At the other extreme, news and reportage from various aspects of American social and political culture present a picture of the United States as a world of race prejudice, inadequate welfare systems, random violence, corrupt politicians, and inferior administrative competence. The Danish citizen has occasion to celebrate a racial tolerance that is free for the having as well as a social system which seems almost magnanimous by comparison. Danish politicians appear halfhonest in the company of the corrupt. The government apparatus comes to seem mindful of the public good. The result is an assimilation to the forms of power that are cherished by the modern state.

As the official edition of American life is made familiar, although American "problems" appear to the citizen to be on a greater scale, the modern principles of power accumulation are turned into the authoritative guide to Danish life. A precise formulation of this process was given by Skard as early as 1946 upon his return to America. He "admonished" the Norwegian students on board the transatlantic liner to "judge America as Norwegians." While immediate experience of America is now mediated by the state, the formula remains the same. The citizen in front of the television is asked to make up his mind about America by reference to un- 
questioned principles of judgment that themselves are strengthened in the process of judging. The assumption of a right to "judge" a foreign community prepares the way for a pseudo-politics, since judgment as a political act is meaningless without the obligations that political membership confers upon the judge. Skard's advice, adopted by the Danish state as its policy of interpretation, exhorts visitors to see less than America.

The daily assimilation of American problems, interpreted by official principles, produces a transposition of political language. While pretending to exchange information about America, it turns out that we are really discussing our own future. "America", as Skard put it, becomes a way of understanding ourselves. As one might want to add, "America" becomes also a way to misunderstand ourselves. Whether the result of a comparison between American and Danish institutions is to confirm the efficiency of the one and/or the social responsibility of the other, the discussion is carried out in the implicit assumption that the official interpretation of America represents the norm of political and economic development. The supreme example of this familiarization with American history occurred during the debates leading up to the Danish application for membership of the Conmmon Market. With reference to the United States, the obsolescence of the nation-state was hailed as the coming of continental growth. The enlargement of markets was viewed as both a sure way to guarantee economic expansion as well as a means to make Europe competitive. The understanding of America suggested that the Old World was to modernize in the image of the New.

\section{Rediscovering America}

The historian, in contrast, is committed to distance, not to familiarization. The preservation and renewal of public memory presuppose an imaginative recovery, the effect of which is the looking at the present from the viewpoint of the past. Implied in the viewing of American history is, in addition, a geographical and political distance. Since the historian does not share in the collectivity and the historical identities of the society he or she is studying, the imaginative movement involves a different kind of discipline, similar to the conditions for the foreign observer which Plato put down in Book Twelve of The Laws. 
Plato took pains to seal his imaginary state from bad influences from the outside. Yet, he allowed for a minimal intercourse, the purpose of which was to secure possibilities for political repair. The ideal state would not be able "to preserve its laws intact" if it got used to them "without grasping their raison d'être." "In the mass of mankind," Plato explained, "you will invariably find a number though only a small number - of geniuses with whom it is worth anything to associate, and they crop up just as often in badly-ruled states as in the well-ruled." The citizen, therefore, should be allowed to go abroad "so that he can see to the strengthening of the customs of his country that are soundly based, and to the refurbishing of any that are defective." The severe conception of responsibility involved in going abroad was underlined by procedures of selection and of evaluation, once the observer returned home to report on his investigations. Plato included the death penalty among the possible punishments for observers who returned "corrupted" and "were convicted in court of meddling in some educational or legal question."7 The solemnity of these restrictions stands out when it is recalled that Plato's friend and teacher, Socrates, was put to death for precisely the offense that Plato envisaged to be tempting for foreign observers, that is the charge of meddling in educational questions.

The importance of Plato's strictures lies in his suggestion that the study of foreign countries need not be corrupting, or ideologically infested, as one might say today. Nor is foreign study necessarily destined to become an exercise in the importation of parts and wholes of technological devices, scientific breakthroughs, and organizational models that are supposed to replace our obsolete way of life, as it is expected to fall apart by itself. The emphasis of Plato, it may be noticed, is not only on the seeing of new things, but equally on the broadening of vision which is supposed to result from the observer's absence from his normal surroundings. The benefits of foreign observance accrue not only as a result of acquaintance with foreign culture, but also as a consequence of the creation of a distance of a theoretical nature which allows the observer to develop a form of imagination that separates him from the immediate and frees him, so to speak, from the oppression of the immediate facticity of things and habitual reasons which shield the existing order. The purpose of foreign observance is to return to the beginnings and rediscover new possibilities in the actual conditions. Such is, at least, the enchantment of going abroad for foreign study if one 
is convinced that life in Denmark is richer and more varied than the sum of the theories which have been fashioned for its description.

From early on, America was supposed to have a peculiar ability to enchant the imagination. In his recent book, Beyond Geography, Frederick Turner calls attention to a letter that Columbus wrote to Ferdinand and Isabella of his third voyage: ${ }^{8}$

I have come to the conclusion respecting the earth, that it is not round as they describe, but of the form of a pear, which is very round except where the stalk grows, at which pojnt it is most prominent, or like a round ball, upon one part of which is a prominence like a woman's nipple, the protrusion being the highest and nearest the sky, situated under the equinoctial line, and at the eastern extremity of the sea.... I do not suppose that the earthly paradise is in the form of a rugged mountain, as the descriptions of it have made it appear, but that it is on the summit of the spot, which I have described.

Columbus' perception can perhaps be explained as a kind of leaning backward into a medieval world picture at the very beginning of the modern notion. Important for the present context is not what Columbus had found, but his imaginative recovery of what he had not found. His idea of a worldly paradise may be seen as a lovely precursor of the same faculty which was later given its classical - even if more conventional - expression by Tocqueville in Democracy in America, which contained the famous confession:

I admit that I saw in America more than America; it was the shape of democracy itself which I sought, its inclinations, character, prejudices, and passions; I wanted to understand it so at least to know what we have to fear or hope therefrom. ${ }^{9}$

The notion of imaginative recovery which may be associated with the idea of foreign observance of American history can be seen to overlap the idea of history as collective memory. Both notions converge in a practice of stepping out of the predominant order; they imply a vision at a distance which is necessary for the perception of a functioning whole rather than of isolated parts or "problems", and, finally, both notions are aimed at the refurbishing of principles of interpretation that are neglected if not suppressed by the official society. An illustrative example which contains all three characteristics of genuine theoretical activity was recently worked out by Sheldon S. Wolin of Princeton University. ${ }^{10}$ It is particularly useful because it makes contact with the quotation of the Norwegian woman cited above. It will be recalled that she referred to a form of democratic speech which can barely be 
recognized in the age of media management. It is a mode of communication which may be thought of as "mutal, subjective comprehension and sharing of meaning."11

Wolin argued that American political history may be understood as a struggle between two interpretative principles, each of which consisted of both theory and practical experiences. "In the American political tradition," Wolin explained, "the people has had two 'bodies,' with each standing for a different conception of collective identity, of power, and of the terms of power. In one of these bodies the people was conceived to be politically active, while in the other it was essentially, though not entirely, passive. The one collectivity was political and democratic and can be called a body politic; the other was primarily economic and intentionally antidemocratic and it can be called a political economy." While the classic expression of the body politic is contained in the Declaration of Independence and the Articles of Confederation, the conception of political economy was set forth in the Constitution, the Federalist Papers, and Hamilton's state papers. While the body politic was formed by the Revolution of 1776, the political economy was instituted by the ratification of the Constitution. Wolin shows that the radical political innovation of the Declaration was its conception of a new political being that went "beyond Aristotle's political man, who knew how to rule and be ruled in turn. The Declaration envisaged a being who would not just participate in politics, but would join in actually creating a new political identity, to 'institute,' 'alter,' or 'abolish' governments, to lay a 'foundation' and to organize power." 12 The body politic remained in existence throughout the nineteenth century under increasing pressure from the political economy, which finally, after the Second World War, established itself as the modern state. The political element of the political economy is now represented by the state, "especially the president and the giant military-administrative establishment of which he is the formal head." The "economy" stands for "a system for the production, consumption, and the use of goods and services." It is characterized by "disproportionately large amounts of power, resources, and money" which have been distributed among "a relatively small number of great corporations."13 


\section{The Abandonment of Collective Memory}

I have quoted copiously from the writings of Sheldon S. Wolin because they appear to me to contain the gravest expression of what one might see in American history - more than American history. What emerges is the recognition of the shape of a European future characterized by an uncanny confounding of what our leaders have designed for us and of the popular fears that our place in the world will vanish as a political land. What will be left over is an ethnic minority stranded in one corner of the European continent. The gospel that is now being preached to us is the principle of "unlimited growth," administered by supernational corporations and multi-national bureaucracies. As the taste for unlimited growth turns sour, we will be prodded on by warnings of unlimited poisoning, administered by powers the meaning of which, without recourse to mystical or religious language, is simply beyond the grasp of any human sensibility and therefore all the more inviting for computerized calculation and bureaucratic manipulation. The vision of unlimited growth and of unlimited death - and their mix-up in the military-industrial economy - escapes one but for brief moments, because the vision is intolerable. Forgetful of our past, we shall soon be taught to forget the future. The suppression of this vision of the real nature of the kinds of power that are preached by the modern state with reference to its revision of American history and culture will be seen to indicate the secret, the hidden stakes of the engagement in American history. It creates the peculiar condition for the study of American history in Denmark.

As the university is being forced into providing the needed services to the regional state of planning and the European state of market, American studies in Denmark will be under increasing pressure to conform to the official view of America. American studies will be seen by the authorities who allocate funds as a small academic investment with which to make Europe competitive. The function will not be a replay of the cruder notions of proAmericanism and anti-Americanism that were played out over the first Cold Wars. The spirit will instead be one of expert advice as the emphasis will be upon the need to avoid a repetition of American failures and the need to copy American successes. The more important result, however, will be to undermine the claims to a political existence which have accumulated over the many years in 
which we have perceived ourselves as members of a political being bound by a heritage of definite place.

The notion of history as collective memory is itself an idea which does not court much favor in professional circles. In his address from 1974, as president of the American Historical Association, Lewis Hanke strongly backed "the movement for a closer association of historians on an international basis." He pointed out, however, "a final problem":

Do all nations - including the United States - need parochialism, naiveté, and myth to bind together their people? Does everyone need to cultivate selfsustaining, self-satisfying, and supportive notions about the virtues and unique qualities of the tribe he belongs to? Perhaps so, and if the tribal history can be kept within decent bounds by the perspectives of historians inside and outside the tribe, it may serve a useful purpose ${ }^{14}$

Hanke's question is sweeping and unqualified: how far should provincial foolishness be suffered gladly? The answer is equally simple: in the interest of keeping the fools happy, it should be suffered so far as its preserve can be policed by professional historians. The simultaneous emphasis on both childishness and crafty calculation, seen to inhere in local forms of knowledge, would seem to indicate how little is worth preserving of the endless variety and complexity of past beliefs. The quotation expresses an habitual liberal tolerance that is disquieting, not because it is extreme - which it is not - but because its author is known to have spent most of his professional life in a highly respected attempt to recreate the history of Central and Latin American Indian nations that were virtually wiped off the map by the Conquistadores.

What is most disquieting about Hanke's theoretical view, inexplicably at odds with the historical parts of his address, is the loss of historical discernment, so that propaganda becomes virtually indistinguishable from significant political communication about shared responsibilities and common involvements. This is precisely the loss that the student of foreign history must face at every step, since he or she does not bring to the chosen field the historical identities required for this kind of judgment. "Sources" come to the student of foreign history in a clean, sublimated form without the unconscious understandings, without the secret belongings and responsibilities that are normally worked out in disciplined fashion in historical writing. History, written by foreigners, will often tend toward efficient, social scientific neatness - a kind of methodological 
strip-mining, if a metaphor be permitted. What kind of international methodology, a few years hence, will require that the Norwegian woman's answer be reduced to "naiveté" and Roosevelt's speeches to "self-satisfying notions"? It seems safe to predict that when the grounds of collective memory are abandoned in favor of a basis in a scientific, international organization, the first and decisive loss will be the authority of history itself.

In view of the changing role of the historian as an expert on historical aspects of present problems, it is to be expected that the function of American history in Denmark will replace the loss of political identity with belief in an international, Western culture. The result will be a concealment of the harsher sides of the transition from a national condition to a transnational European state. As early as 1964, this purpose was loudly proclaimed by Professor Ludwig Borinsky from the University of Hamburg:

American leadership in the long run will be possible only if there is an intellectually and morally homogeneous political class in all major industrial nations of the Western world. Such a political class does not exist on the continent, least of all in Germany. ... The essential function of American scholarship will by now have become clear. A large amount of personal contact and assimilation, and of collaboration in common political institutions would be further indispensable conditions. The result would be a class of political leaders and high officials spread over the entire free world who speak the same intellectual language, have a similar moral character, and share a common loyalty. Here is a goal worthy of our best efforts. ${ }^{15}$

Since there is not a whole lot of historical optimism behind the pushing for a new European order - except so far as the bulwark against Bolschevism goes for the true believers - a different kind of legitimation is needed. A necessity of social and economic coordination, formulated with reference to American experience will be long in the waiting. In the same process we will, as a collectivity, be asked to divest ourselves of the traditional skills, shared understandings, common morality and common judgment that make it possible for a people to protest and resist. Submission to Strasbourg and Brussels will be promoted to replace of traditional loyalties and affection for people and place. The emptying of shared recollection will go together with the minorization of our people as we are turned into an ethnic curiosity minority. Adoption of Lucien Febvre's dictum, "history does not exist, only historians exist," will signify an important phase of this process. 


\section{NOTE S}

1 American Studies in Europe. Their History and Present Organization, 2 vols (Philadelphia: University of Pennsylvania Press, 1958), p. 651.

2 Ibid., pp. $641-42$.

3 The American Myth and the European Mind. American Studies in Europe 1776-1960 (Philadelphia: University of Pennsylvania Press, 1961), p. 83.

4 Sheldon Wolin, "The Peoples' Two Bodies," Democracy, Vol I, No. 1, Jan. 1981, p. 13.

5 Alexis de Tocqueville, Democracy in America, translated by George Lawrence (Garden City N.Y.: Douleday Anchor, 1969). Gunnar Myrdal, An American Dilemma, 2 vols (New York): Harper and Bros., 1944.

6 Transatlantica. Memoirs of a Norwegian Americanist (Oslo: Universitetsforlaget, 1978), pp. 76-77.

7 Plato, The Laws, translated by Trevor J. Saunders (London: Penguin Books, 1970), pp. 501-503. Sheldon S. Wolin, "Political Theory," International Encyclopedia of the Social Sciences (New York: Macmillan Co., 1968), Vol XII, 318-331; and "Political Theory and Political Commentary," Political Theory and Political Education, ed. Melvin Richter (Princeton, N.J.: Princeton University Press, 1980), pp. 190-203.

8 Beyond Geography. The Western Spirit Against the Wilderness (New York: Viking Press, 1980).

9 Democracy in America, p. 19.

10 "The People's Two Bodies," pp. 9-25.

11 John H. Schaar, "Legitimacy in the Modern State," Legitimacy in the Modern State (New Brunswick, N.J.: 'Transaction Books, 1981), p. 40.

12 "The People's Two Bodies," pp. 11-13.

13 "Reagan Country," New York Review of Books, Dec. 18, 1980, pp. 9-12.

14 "American Historians and the World Today: Responsibilities and Opportunities," American Historical Review, Vol 80, No. 1, Feb. 1975, pp. 18-19.

15 "The American Scholar and the World," American Studies in Transition, ed. Marshall W. Fishwick (Philadelphia: University of Pennsylvania Press, 1964), pp. 266-67. 